\title{
TOMORROW, THE SUNSET WILL BE BLUE
}

\section{A sight for sore eyes.}

\section{BY JEREMY SZAL}

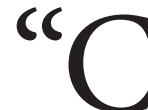

ome on!" With Benn's voice booming in my helmet he sounds

right next to me, even though I'm lagging 20 metres behind. I've never been good at running. I'm even worse now in the low gravity. "Slow coach!"

Usually, I'd tell him to shut up, and keep my own pace. We'll get to see the Dzilt sunset strike a mellow blue against the silvery horizon of the planet, like we do every evening. But knowing what I know, I pick up speed. The big guy's grinning behind his visored helmet as I reach the hill, out of breath and soaked with sweat inside my skin-hugging surface-suit. My chest heaves. "You win," I puff.

"'I'll get there first!' she says," he remarks, still grinning as he gently claps me across the back with a massive gloved paw. It's what I love about him: how he cares to be gentle even with his strength.

We walk shoulder to shoulder along the silvery planes, his breathing a comfortable echo in my ear. He's pale as I'm dark, and a head taller than me. Our sturdy suits, linked to our individual pheromones, have the same bulky cut with thick exterior plating to withstand the occasional metal storms. His is lime green for men; mine a dark purple for women. There's a constant, mild tickling I've never got used to from gel-coated tendrils in my inner suit that monitor my biorhythms. The microbot AIs - being used for research and development on this planet - skitter along the pockmarked surface in search of biodiversity to absorb into their tiny bodies. The outpost we're stationed at is a corrugated smudge at our backs. It's the only one for 50 klicks.

We pause for Benn to readjust the broad brown straps of my utility harness that runs in an X across my back and chest. He insists on it, now. Can't be too careful with gear checks on a planet where breathing in the metal dust could kill you; to say nothing of the toxic atmosphere. People thought we were crazy to leave Coloven to come here, especially being so young, but there's nothing like the thrill of being some of the first to walk on, and study,

D NATURE.COM Follow Futures:

y @NatureFutures

f go.nature.com $/ \mathrm{mtoodm}$ a new planet.

"I hope you don't mind coming so far out," I say over my shoulder.

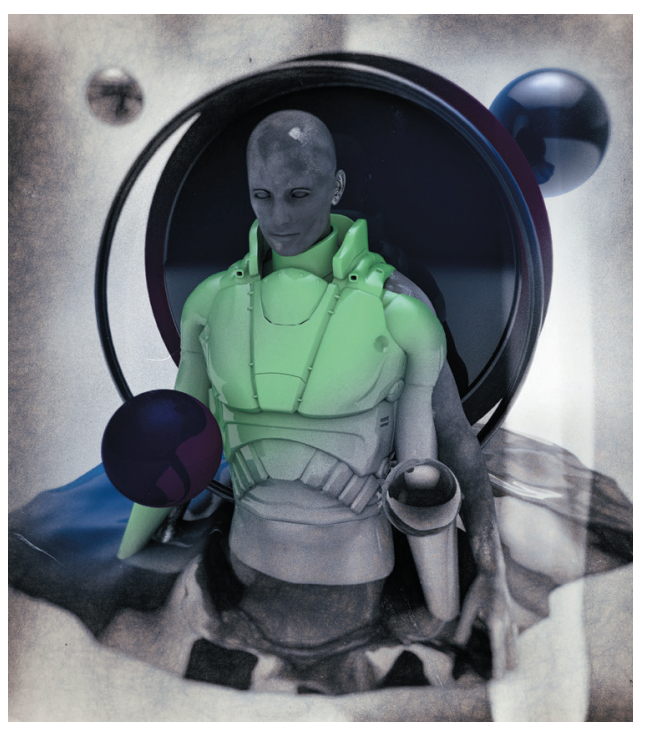

"I like walking with you, Sola," he says, not even panting as we ascend another steep hill. Sweat's pooling under my arms and dripping down my spine as we arrive at the top. "Now there's a sight," the big guy says.

Our visors auto-polarize as we peer into the horizon. The distant sun is slowly sinking behind razorbacked rocks and the twisting spines of the mountains, sharpened from millennia of exposure to the metal storms. Spikes and crags shatter the light into silver-blue arcs along the rolling planes. We stand, back to back, heads tilted as we slowly turn and take in the full circumference of the view. Alien planes and plateaus, and weathered grasslands as far as the eye can see. It's breathtaking in its wildness. It's untouched. Uncolonized. Its harshness a beauty.

And a danger.

I swallow and focus on Benn and his rushed, excited breathing as we drink in the sights together. His bulky weight against my body a comforting pillar. We sit side by side, legs dangling over the precipice. Microbots skitter around us, twirling up Benn's suit arm. I notice. He doesn't.

"Never going to see something like that on Coloven," he says, knocking his bulky shoulder into mine and making my harness buckles rattle. Then he's silent for the longest time. He doesn't want to shatter the moment, but it's because of this pause I know it's coming. "They don't know yet, do they?"

I close my eyes. Delaying reality for a second longer. "No." I don't want to turn to him, but I do. “They don't know you're dead yet."

Base doesn't know my helmet seal broke on our way to this very place. They don't know Benn's last actions were giving me his own helmet, saving me, before the toxic gases rotted his insides and the metal dust clogged his throat. They don't know I got every microbot I could find to eat his body. Absorbing his flesh, blood and bones, and reassembling them into his exact body shape, down to his flecks of red stubble. They don't know I programmed the microbots with an AI copy of his persona from the database, reprogramming it to fit him just as I remember.

They don't know, because if they do they'll withdraw us from the planet and retrieve the microbots I've stolen from their research department, wiping him forever. He's just a number to them. They won't hesitate to pull the plug if it stops bad PR. This way, we're together for a short time longer. This way, we can still race to see the sunset like we did every day when he was alive. How long it will be until they discover the truth, I don't know.

Benn turns again to the silvery sun as it finally sets, and throws a slow blanket of darkness across the grassy planes. "I could stare at it forever," he breathes, draping an arm across my shoulders.

"I know," I say, meaning it more than he'll ever know.

"It's going to be there tomorrow, of course."

"I know."

He removes his helmet despite the suit's chirping warnings. It's not like he needs it. His head dissolves into a blur of glistening microbots, like a rippling waterfall of black pebbles, before reassembling back into the facade of a human face. He's already breaking down.

Suddenly, he throws me flat on my back and stands over me, grinning his wide grin. "Race you back, Sola!" he yells, already halfway down the hill.

I pick myself up, swallowing hard before putting on my usual smile and chasing him down the hill into the roaring darkness.

Jeremy Szal is the author of many short stories and the space opera novel Stormblood, from Gollancz in February 2020. He lives in Sydney, Australia. Get in touch at jeremyszal.com or @jeremyszal. 